\title{
Soil moisture obtained through remote sensing to assess drought events
}

\author{
Tiago de M. Inocêncio ${ }^{1}$, Alfredo Ribeiro Neto ${ }^{1}$ \& Alzira G. S. S. Souza ${ }^{1,2}$ \\ ${ }^{1}$ Universidade Federal de Pernambuco/Programa de Pós-Graduação em Engenharia Civil. Recife, PE, Brasil. E-mail: tminocencio@gmail.com - ORCID: \\ 0000-0003-2801-6189; alfredo.ribeiro@ufpe.br (Corresponding author) - ORCID: 0000-0002-9411-0651; saxzira@yahoo.com.br - ORCID: 0000-0003- \\ $0152-6066$ \\ ${ }^{2}$ Instituto Federal de Educação, Ciência e Tecnologia Baiano/Núcleo de Agrimensura. Uruçuca, BA, Brasil
}

\begin{abstract}
The sequence of drought events in the Northeast of Brazil in recent decades raises attention to the importance of studying this phenomenon. The objective of this study was to evaluate the duration and severity of drought events from 1988 to 2018 in hydrographic basins of the state of Pernambuco, Brazil, using two drought indexes: Standardized Soil Moisture Index and Soil Moisture Condition Index, calculated based on data of the Soil Moisture Project of the European Space Agency's Climate Change Initiative. The duration of the droughts was determined considering the months between their beginning and end, and their severity was based on the area formed in the graph between the curve of the index and the x-axis. The soil moisture database showed to be a promising tool for the analysis and monitoring of drought events in the Northeast region of Brazil, mainly for analysis and monitoring of drought events. The indexes allowed the evaluation of the drought phenomenon over the 30-year period, showing increases from 2012, which were more pronounced in the Semiarid region. The hydrographic basins responded differently to a same event, depending on the climate characteristics of the region in which they are located. Consecutive years with rainfall below the historical mean increased the magnitude of the droughts, as found for the 2012-2017 period, in which the indexes presented delays to return to more favorable values, showing the effect that one drought year has on the following year.
\end{abstract}

Key words: drought indexes, soil moisture condition index, standardized soil moisture index

\section{Umidade do solo obtida por sensoriamento remoto para análise de eventos de seca}

RESUMO: A sequência de eventos de seca no Nordeste do Brasil ocorridos nas décadas recentes chama a atenção para a importância de se estudar este fenômeno. Este artigo tem por objetivo avaliar a duração e a severidade de eventos de seca, para as bacias hidrográficas do Estado de Pernambuco, durante o período de 1988 a 2018, utilizando-se dois índices de seca: o Standardized Soil Moisture Index e o Soil Moisture Condition Index calculados com dados da base European Space Agency's Climate Change Initiative Soil Moisture. A duração da seca foi determinada contabilizando-se os meses entre o início e o fim e a severidade foi dada pela área formada no gráfico entre a curva do índice e o eixo-x. A base de dados de umidade do solo mostrou-se promissora para utilização na região Nordeste do Brasil, particularmente, para a aplicação na análise e acompanhamento de eventos de seca. Os índices permitiram avaliar o fenômeno da seca no período de 30 anos, evidenciando aumento a partir do ano de 2012, sendo mais acentuado na região semiárida. As bacias hidrográficas respondem de forma distinta para um mesmo evento, a depender da característica climática da região em que está localizada. Anos consecutivos com precipitação abaixo da média histórica amplificam a magnitude da seca, como observado no período entre 2012 e 2017, em que os índices apresentam dificuldade para retornar a valores mais favoráveis, mostrando a influência que um ano seco exerce sobre o ano seguinte.

Palavras-chave: índices de seca, soil moisture condition index, standardized soil moisture index 


\section{INTRODUCTION}

Several climatic phenomena occurred in Brazil in the 2010's affected socioeconomic aspects of the society. The occurrence of drought events stands out in this period for several regions of the country, especially the Northeast region, where important impacts on agriculture occurred due to the drought period that begun in 2012, causing decreases of approximately $29 \%$ in grain production (Zeri et al., 2018). Several studies have been conducted to evaluate the droughts from 2012 to 2017 using rainfall data series and vegetation indexes (Brito et al., 2017; Cunha et al., 2017; 2018). Soil moisture is an essential climatic variable to monitor droughts, which is considered an important variable for establishing the severity of drought (Pablos et al., 2017; Rossato et al., 2017; Souza et al., 2018). This is an important variable to establish the severity of droughts that is used mainly to monitor droughts for agricultural purposes (Pablos et al., 2017; Paredes-Trejo \& Barbosa, 2017; Souza et al., 2018).

The present study proposes the use of remote sensing with global coverage and long-period data for analyses of historical and current drought events to characterize, historically, the current period in terms of magnitude of droughts. Standardized indexes have been used to assess droughts, providing a solid base for studies on this issue (Wood \& Sheffield, 2012; Oertel et al., 2018). Therefore, the objective of this study was to evaluate the duration and severity of drought events from 1988 to 2018 in hydrographic basins of the state of Pernambuco, Brazil, using two drought indexes that are based on the soil moisture: Standardized Soil Moisture Index and Soil Moisture Condition Index, calculated based on data of the Soil Moisture Project of the European Space Agency's Climate Change Initiative.

\section{Material ANd Methods}

The state of Pernambuco is in the Northeast region of Brazil, between the coordinates $7^{\circ} \mathrm{S}$ and $10^{\circ} \mathrm{S}$ and $34^{\circ} \mathrm{W}$ and $42^{\circ} \mathrm{W}$. It extends considerably from east to west, with $80 \%$ of its territory in the Semiarid region (CONDEPE/FIDEM, 2006; Souza et al., 2018).

Pernambuco state is divided into three areas regarding its climatic characteristics, 'Sertão', 'Agreste', and Coast regions. The 'Sertão', in the west part of the state, has high evaporation rates, resulting in water deficits (potential evapotranspiration higher than rainfall) and dry periods from April to November; the rainfall is concentrated in four months, with peaks occurring in the period of March to April. The 'Agreste' is a transition area from semiarid to subhumid, with rainfall concentrated from February to May (Pernambuco, 2005). The 'Sertão' and 'Agreste' are very different from the Coast region, which presents subhumid climate and annual rainfall above $1,000 \mathrm{~mm}$.

The government of Pernambuco organized the hydrography data of the state by the State Plan for Water Resources, dividing the state into 29 Planning Units (PU), comprising 13 river basins (Goiana, Capibaribe, Ipojuca, Sirinhaém, Una, Mundaú, Ipanema, Moxotó, Pajeú, Terra Nova, Brígida, Garça, and Pontal), which are the most important water resources of the state (CONDEPE/FIDEM, 2006). In addition, there are six groups of small river basins in the coastal region (GL1 to GL6), nine groups of small river basins in the interior of the state (GI1 to GI9), and a small river basin that compose the drainage network of the Fernando de Noronha archipelago.

The present study considered a rearrangement of the PU that resulted in 22 hydrographic basins, which were the most important for Pernambuco state. This geographical arrangement allowed a better use of information for water management, since the soil moisture is related to the effects of droughts, and agriculture. Table 1 and the Figure 1 present the PU in the three areas with similar climatic characteristics: Coast, 'Agreste', and 'Sertão'.

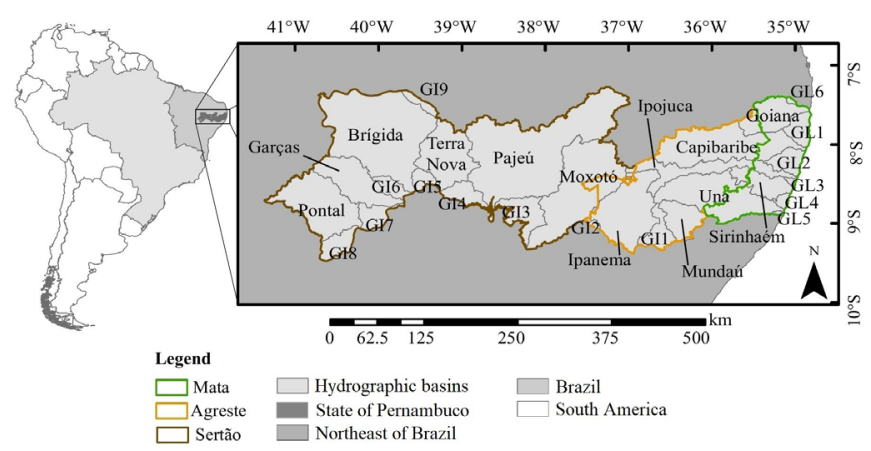

Figure 1. Hydrographic basins of the state of Pernambuco, Brazil

\section{Soil moisture data}

The soil moisture data were obtained from the Soil Moisture Project of the European Space Agency's Climate Change Initiative (ESA, 2018) by combining several soil moisture products from the active and passive microwave instruments transported by several satellite platforms, with daily temporal resolution and spatial resolution of $25 \mathrm{~km}$, over approximately

Table 1. Planning units used in the study

\begin{tabular}{|cccccc}
\hline $\begin{array}{c}\text { Planning } \\
\text { unit }\end{array}$ & $\begin{array}{c}\text { Hydrographical } \\
\text { basin }\end{array}$ & $\begin{array}{c}\text { Area } \\
\left(\mathbf{k m}^{2}\right)\end{array}$ & $\begin{array}{c}\text { Planning } \\
\text { unit }\end{array}$ & $\begin{array}{c}\text { Hydrographical } \\
\text { basin }\end{array}$ & $\begin{array}{c}\text { Area } \\
\left(\mathbf{k m} \mathbf{2}^{2}\right.\end{array}$ \\
UP01 & Goiana & 2968.21 & UP12 & Garcas & 4158.60 \\
UP02 & Capibaribe & 7454.88 & UP13 & Pontal & 6132.62 \\
UP03 & Ipojuca & 3437.46 & UP14 & GL1 & 1188.11 \\
UP04 & Sirinhaem & 2512.01 & UP15 & GL2 & 1264.94 \\
UP05 & Una & 6807.80 & UP16 & Gl1 & 1382.57 \\
UP06 & Mundau & 2220.04 & UP17 & Gl3 & 2303.48 \\
UP07 & Ipanema & 6392.68 & UP18 & Gl4 & 1322.78 \\
UP08 & Moxoto & 9800.17 & UP19 & Gl5 & 715.56 \\
UP09 & Pajeu & 16933.08 & UP20 & Gl6 & 849.94 \\
UP10 & Terra Nova & 4959.14 & UP21 & Gl7 & 1223.64 \\
UP11 & Brigida & 14487.38 & UP22 & Gl8 & 542.93 \\
\hline
\end{tabular}


40 years (November 1, 1978 to June 30, 2018) (Liu et al., 2012; Carrão et al., 2016; Paredes-Trejo \& Barbosa, 2017, ESA, 2018). The soil moisture product used was the ESA-CCI-SM version v04.4 (formerly named soil moisture ECV product). Only products after 1988 were used, comprising 30 years of data, which were converted into monthly data.

The data was composed of microwave products of remote sensing arranged as: a data set from active sensors, data from passive sensors, and the combined data set of these two (Carrão et al., 2016).

The products of active microwave use sensors that work in band $\mathrm{C}$ in the ERS-1, ERS-2, MetOp-A, and MetOp-B. The passive microwave sensors were SMMR, SSM/I, TMI, AMSR-E, WindSat, AMSR-2, and SMOS. The combined products were composed of all active and passive L2 products (Liu et al., 2012; ESA, 2018).

\section{Standardized Soil Moisture Index (SSMI)}

The SSMI was obtained from standardized soil moisture data following the methodology proposed by McKee et al. (1993) for the calculation of the Standardized Precipitation Index (SPI), which is obtained through the following steps: 1) obtaining temporal series of the specific variable for a period, e.g., monthly rainfall or soil moisture data; 2) applying the proper probability function for the data obtained in item 1 to choose accumulated periods, e.g., 3, 6, or 12 months; 3) obtaining the cumulative probability; 4) applying the inverse function to obtain the standardized values of normal distribution, i.e., values with mean 0 , and standard deviation 1 .

The SSMI is an agricultural index to obtain the normalized soil moisture, which denotes how much the value of this variable is distant from the mean, due to the standard deviation of a data series, thus basing on the standard normal distribution. This index can be calculated for different time scales (monthly, trimestral, semiannual, and annual).

Only the scales of 6 and 12 months were used. The probability function adopted for the SSMI was the log-logistic used by Oertel et al. (2018), which considers that the soil moisture data series fits well to this distribution function.

\section{Soil Moisture Condition Index (SMCI)}

The SMCI is linearly dimensioned between 0 and 100 for each pixel, based on the minimum and maximum absolute values, where values closer to 0 indicate drought conditions, and closer to 100 indicate higher moisture conditions (Zhang \& Jia, 2013). This calculation follows the method used by Kogan (2002) for the application of the Vegetation Condition Index. The SMCI is a soil moisture index adequate to monitor shortterm drought conditions and is more sensitive to land use than other indexes (Zhang et al., 2017); it was calculated using Eq. 1

$$
\mathrm{SMCI}_{\mathrm{i}}=100 \cdot \frac{\mathrm{SSM}_{\mathrm{i}}-\mathrm{SSM}_{\text {min }}}{\mathrm{SSM}_{\text {max }}-\mathrm{SSM}_{\text {min }}}
$$

where:

SSMi - soil moisture in the month i;

SSMmin - minimum soil moisture referring to the whole study period; and,
SSMmax - maximum soil moisture referring to the whole study period.

\section{Drought duration and severity}

The concepts of drought duration and severity are connected to the intensity of the drought period. These variables were calculated on a month scale, from 1988 to 2018 for the SSMI and SMCI. The key in the calculation of drought duration and severity is the definition of the beginning and end of the drought event. The drought duration is the number of months from the beginning (included) and the end of the event (not included), and the severity is the area formed in the graphic between the curve of the index and the $x$ axis, for the beginning and the end of the event (Brito et al., 2017; Mishra \& Singh, 2010).

The value - 1 was used to indicate the beginning of the event for the SSMI, following the same method used for SPI in studies that described drought events (McKee et al., 1993; Spinoni et al., 2014; Brito et al., 2017). The end of drought events was defined as the time in which the index become positive again. The event was defined for the SMCI based on Brito et al. (2017) and Kogan (2002), considering that the beginning of the event occurs when the values are lower than or equal to 30 and ends when the index is higher than 45 .

Complementarily, a third indicator of magnitude was calculated by dividing the severity by the duration, which was called intensity (Mishra \& Singh, 2010). The intensity indicator is the mean severity value during the event.

\section{Results ANd Discussion}

The duration, severity and intensity of the drought events were calculated considering the whole period with soil moisture data from January 1988 to June 2018. Figures 2, 3, and 4 show the spatial variability of the drought indicators duration, severity and intensity, respectively.

No well-defined spatial pattern was found within and between indicators of magnitude; for example, considering only the duration, different patterns are found for SSMI-6, SSMI-12, and SMCI. A relative similarity was found for the results of SSMI-6 and SMCI for the indicators duration and intensity. This was probably due to the spatial discretization of hydrographic basins; the use of a more refined spatial discretization would make the variation milder and facilitate the identification of patterns.

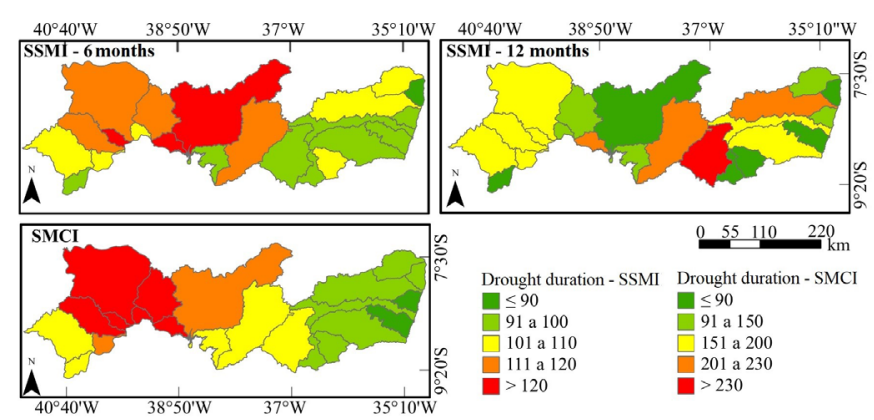

Figure 2. Duration of drought events from 1988 to 2018 in hydrographic basins of the state of Pernambuco, Brazil, given in number of months, based on the Standardized Soil Moisture Index (SSMI) and Soil Moisture Condition Index (SMCI) 


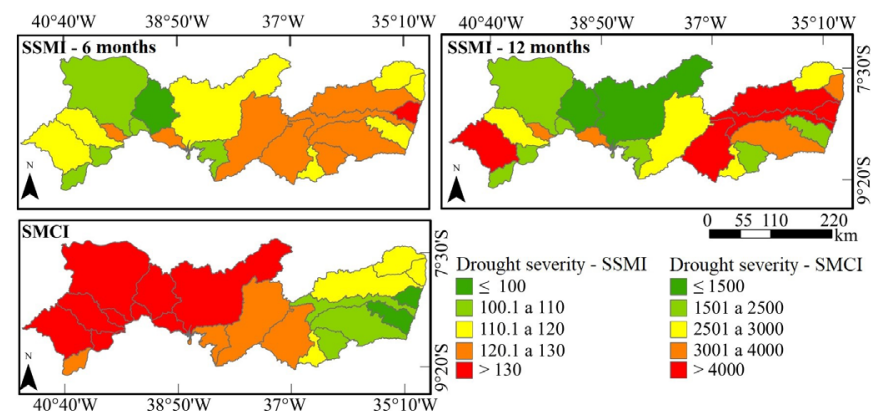

Figure 3. Severity of drought events from 1988 to 2018 in hydrographic basins of the state of Pernambuco, Brazil, based on the Standardized Soil Moisture Index (SSMI) and Soil Moisture Condition Index (SMCI)

SSMI-6 and SMCI presented longer duration for the basins in the Sertão region, and higher intensity for the basins in the 'Agreste' and Coast regions. Considering the two timescales used for SSMI ( 6 and 12 months), 16 of the 22 basins had higher duration for SSMI-6, indicating a prevalence of short-term occurrences. The severity map showed 13 basins with higher magnitude for SSMI-12, whereas the intensity of 17 of the 22 basins presented more critical values for SSMI-6.

The results of the SSMI and SMCI were more detailed analyzed using one basin of each region regarding climatic characteristics ('Sertão', 'Agreste', and Coast), due to the large number of basins. PU01, a basin of the Goiana River, was selected for Coast region; PU07, a basin of the Ipanema River, was selected for the 'Agreste' region; and PU09, a basin of the Pajeú River, was selected for the 'Sertão' region. The results of the basins selected for the SSMI and SMCI are shown in Figures 5 and 6, respectively.

The SSMI results showed two long drought periods (19881992 and 1998-2000) in the two timescales for the planning unit of the Goiana River (Coast). It also shows the most recent drought period, which started in 2012. The SMCI presented low values (Figure 6), i.e., intense drought in these periods, but high temporal variability. This was probably because the SMCI is calculated using a month timescale, presenting higher data variation than the other indexes used.

The SSMI results of the Ipanema planning unit were similar to those of the Goiana River basin for the periods 1988 to 1992 and 1998 to 2000. The drought was more intense for the period 2012 to 2017, with a small hiatus between 2014 and 2015 for the 6-month, and continuous for 12-month index. According

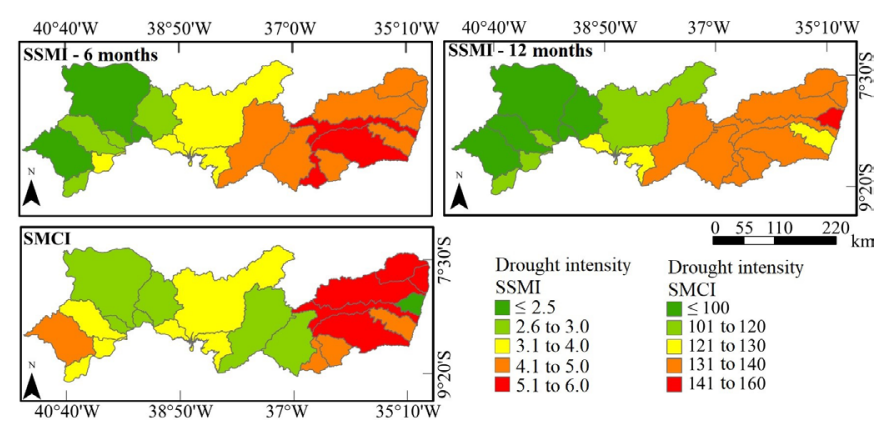

Figure 4. Intensity of drought events from 1988 to 2018 in hydrographic basins of the state of Pernambuco, Brazil, based on the Standardized Soil Moisture Index (SSMI) and Soil Moisture Condition Index (SMCI)

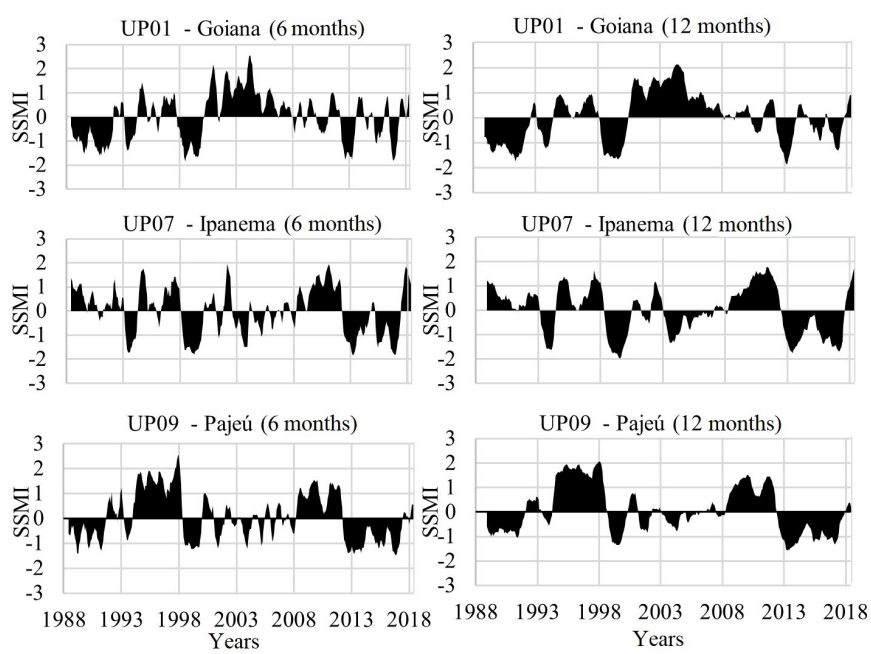

Figure 5. Standardized Soil Moisture Index (SSMI) in the planning units PU01 Goiana, PU07 Ipanema, and PU09 Pajeú, in 6- and 12-month scales

to McKee et al. (1993), the standardized 12-month index present longer drought periods. The SMCI is consistent with the results presented for the SSMI with persistent periods with index values below the threshold that defines the occurrence of drought events.

Souza et al. (2018) evaluated droughts for the state of Pernambuco, Brazil, though rainfall and soil moisture anomalies using the SMOS satellite for 2010 to 2017 and found positive anomalies for the 2010-2011 period; however, the 2012-2017 period had anomalies equal to or lower than $-50 \%$. The most significant droughts in this period were found for the years 2012, 2013, and 2017, with 2012 presenting more negative anomalies for rainfall and soil moisture within the whole studied period, mainly in the 'Agreste' region.

The data obtained for 'Sertão' region, represented by the Pajeú basin, showed a high-intensity drought period for the 1989-1992 period, and more significant droughts for the most recent period, as indicated by the SSMI. These periods also were more intense by the SMCI, with values near zero, indicating very drought conditions.

Barbosa et al. (2019) evaluated the impact of droughts on the vegetation of the Caatinga biome in the Northeast region of Brazil from 1901 to 2016 using SPI and found that 1991, 1992, 1993, 1998, 2007, 2012, and 2016 were the years with SPI $<-1$; and the longest period of consecutive years with total seasonal rainfall below the mean was 2010-2016, with

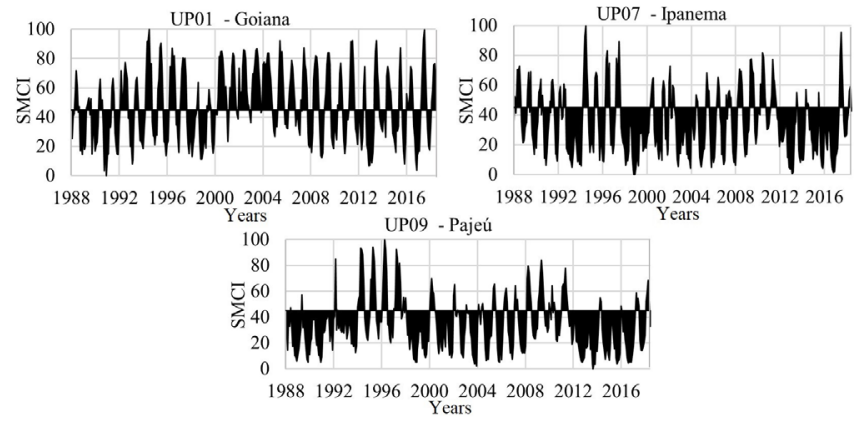

Figure 6. Soil Moisture Condition Index (SMCI) in the planning units PU01 Goiana, PU07 Ipanema, and PU09 Pajeú 
more critical values for 2012. This indicates that the impact increases as the drought periods is increased, as found for the SSMI results in the present study, and by Cunha et al. (2017), who raised attention to the effect that a drought year has on the following year.

The duration and severity were calculated for the three basins selected using data under a five-year scale. This allowed the identification of drought events with higher magnitude and the comparison between them. The most recent drought period (2012 to 2018) presented high magnitudes of duration and severity (Figure 7), mainly for the basins in the Semiarid region (Ipanema and Pajeú).

Brito et al. (2017) found similar results when evaluating the duration, severity, and frequency of droughts in the Brazilian semiarid in 5-year periods from 1981 to 2016 and found that the 2011-2016 period had more severe and significant droughts.

The results obtained show differences between the analyzed areas. The basins in the 'Sertão' and 'Agreste' regions (characterized by semiarid climate) had events in the early 1990 's, and in the 1997-1998 period presented less critical results than those in the Coast region. The opposite is found for events in the 2012-2017 period, in which the basins in the Semiarid region presented more critical values. Climate and physical characteristics can explain these differences between regions, such as soil type and land use.

The 'Sertão' and 'Agreste' regions have shallow soils due to their geological formation and land cover with predominance of Caatinga vegetation and pastures, whereas the Coast region has deeper soils and the predominant land use is for agriculture and pastures. Therefore, the rainfall values below historical mean and the soil characteristic contributed to make the drought events of higher duration more critical in the Semiarid region than in the Coast region.

Hydrographic basins of the state of Pernambuco, Brazil, may show differences in drought events because they are in areas with different climates, and they are affected by different climate systems. The effects of El Niño and La Niña Southern Oscillation events in Brazil vary considerably depending on the region (Carrão et al., 2016). Rainfall in the North and Northeast regions (including Pernambuco) decreases during El Niño events, increasing drought periods, severities, and durations, as occurred in 1993, when a clear natural distortion of the phenomenon was observed (Carrão et al., 2016). The critical values of periods described in Figure 7 show the

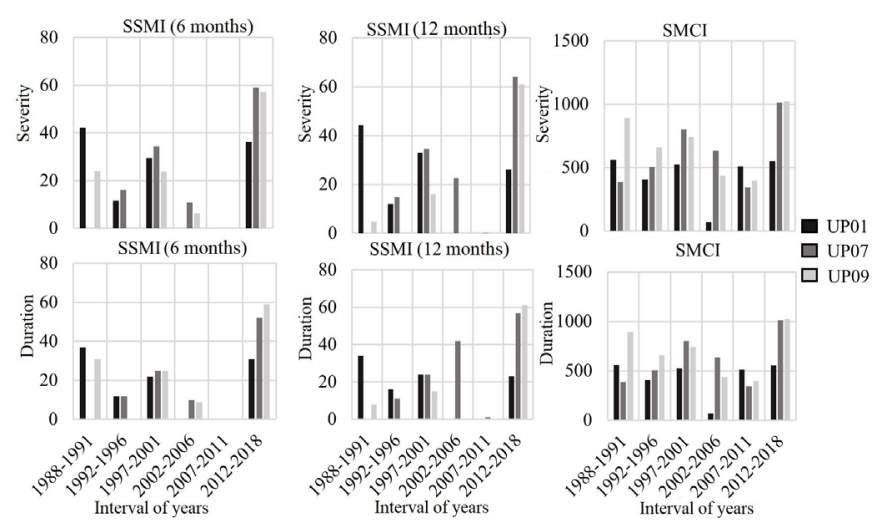

Figure 7. Severity and duration of drought periods in the planning units PU01 Goiana, PU07 Ipanema, and PU09 Pajeú occurrence of these events. Marengo et al. (2018) reported that recurrent drought periods may have begun in the middle 1990 's, with interruption by some rainy years $(2008,2009$, and 2011). Mishra \& Singh (2010) performed similar evaluations for drought events occurred in North America, Europe, Asia, Australia, and Africa.

The results found in the present study confirm those from analyses of other studies, which found exceptional magnitude for the recent drought event (2012-2017) in the Northeast region of Brazil. The studies show that this event had higher magnitude in the last 30 years (Marengo et al., 2018, ParedesTrejo \& Barbosa., 2017), and reached a larger area of the Northeast region of Brazil (Cunha et al., 2018).

The lack of planning of actions is a major problem when dealing with drought events, denoted by the management of the crises instead of management risks focused on reducing the damages caused by the event. The management of risks include increasing the resilience of the system, which depends on monitoring, forecasts, and alerts for decision making at the correct time. The drought indexes used in the present study can be useful for monitoring the evolution of drought on a large scale (e.g., hydrographic basins, territory of a state, or the territory of Northeast region of Brazil), as is done by the Northeast Drought Monitor, which uses rainfall data series for the monitoring.

\section{Conclusions}

1. The database of the Soil Moisture Project of the European Space Agency's Climate Change Initiative showed to be a promising tool for the analysis and monitoring of drought events in the Northeast region of Brazil.

2. The duration and severity of drought events calculated by the Standardized Soil Moisture Index (SSMI) and Soil Moisture Condition Index (SMCI) allowed the evaluation of the drought phenomenon in the state of Pernambuco, Brazil, in a 30-year period, denoting increases of this phenomenon after 2012, which were more pronounced for the Semiarid region.

3. Consecutive years with rainfall below the historical mean increase the magnitude of the droughts.

\section{ACKNowledgements}

This paper is a contribution of the research financed by the contract no. 104/2017 of the Fundação de Apoio ao Desenvolvimento of the Universidade Federal de Pernambuco, and the project financed by the Inter-American Institute for Researches in Global Changes (IAI; CRN3056), which is supported by the U.S. National Science Foundation (Grant GEO-1128040).

\section{Literature Cited}

Barbosa, H. A.; Kumar, T. V. L.; Paredes, F.; Elliott, S.; Ayuga, J. G. Assessment of Caatinga response to drought using MeteosatSEVIRI Normalized Difference Vegetation Index (2008-2016). ISPRS Journal of Photogrammetry and Remote Sensing, v.148, p.235-252, 2019. https://doi.org/10.1016/j.isprsjprs.2018.12.014 
Brito, S. S. B.; Cunha, A. P. M. A.; Cunningham, C. C.; Alvalá, R. C. S.; Marengo, J. A.; Carvalho, M. A. Frequency, duration and severity of drought in the Semiarid Northeast Brazil region. International Journal of Climatology, v.38, p.517-529, 2017. https://doi.org/10.1002/joc.5225

Carrão, H.; Russo, S.; Sepulcre-Canto, G.; Barbosa, P. An empirical standardized soil moisture index for agricultural drought assessment from remotely sensed data. International Journal of Applied Earth Observation, v.48, p.74-84, 2016. https://doi. org/10.1016/j.jag.2015.06.011

CONDEPE/FIDEM - Agência Estadual de Planejamento e Pesquisas de Pernambuco. Bacia Hidrográfica do Rio Una, GL4 e GL5. Série Bacias Hidrográficas de Pernambuco No 3. Recife: CONDEPE/ FIDEM, 2006, 85p.

Cunha, A. P. M. do A.; Brito, S. S. de B.; Rossato, L.; Alvalá, R. C. dos S.; Carvalho, M. A.; Zeri, M.; Cunningham, C.; Maciel, A. P. dos R.; Andrade, E. S.; Vieira, R. M. da S. P. Avaliação de indicador para o monitoramento dos impactos da seca em áreas de pastagens no semiárido do Brasil. Revista Brasileira de Cartografia, No 69/1, p. 89-106, 2017.

Cunha, A. P. M. do A.; Tomasella, J.; Ribeiro-Neto, G. G.; Brown, M.; Garcia, S. R.; Brito, S. B.; Carvalho, M. A. Changes in the spatial-temporal patterns of droughts in the Brazilian Northeast. Atmospheric Science Letters, 19, 1-8, 2018. https:// doi.org/10.1002/asl.855

ESA - European Space Agency. Climate Change Initiative Phase 2 Soil Moisture. Product Specification Document (PSD) D1.2.1 Version 4.2. Earth Observation Data Centre for Water Resources Monitoring (EODC) GmbH. Hamburg: University of Hamburg, 2018. 50 p.

Kogan F. N. World droughts in the new millennium from AVHRR-based vegetation health indices. EOS Transactions American Geophysical Union, v.83, p.562-563, 2002. https://doi. org/10.1029/2002EO000382

Liu, Y. Y.; Dorigo, W. A.; Parinussa, R. M.; Jeu, R. A. M. de; Wagner, W.; Mccabe, M. F.; Evans, J. P.; Dijk, A. I. J. M. van. Trend-preserving blending of passive and active microwave soil moisture retrievals. Remote Sensing Environment, v.123, p.280-297, 2012. https://doi. org/10.1016/j.rse.2012.03.014

Marengo, J. A.; Alves, L. M.; Alvalá, R. C. S.; Cunha, A. P.; Brito, S.; Moraes, O. L. L. Climatic characteristics of the 2010-2016 drought in the semiarid Northeast Brazil region. Anais da Academia Brasileira de Ciências, 90, 1973-1985, 2018. https:// doi.org/10.1590/0001-3765201720170206

McKee, T.; Doesken, N.; Kleist, J. The relationship of drought frequency and duration to time scales. In: Proceedings of the Eighth Conference on Applied Climatology. Boston: American Meteorological Society. p.179-184, 1993.
Mishra, A. K.; Singh, V. P. A review of drought concepts. Journal of Hydrology, v. 391, p. 202-216, 2010. https://doi.org/10.1016/j. jhydrol.2010.07.012

Oertel, M.; Meza, F. J.; Gironás, J.; Scott, C. A.; Rojas, F.; PinedaPablos, N.; Drought propagation in semi-arid river basins in Latin America: Lessons from Mexico to the Southern Cone. Water, v.10, p.1-21, 2018. https://doi.org/10.3390/w10111564

Pablos, M.; Martínez-Fernández, J.; Sánchez, N.; González-Zamora, Á. Temporal and spatial comparison of agricultural drought indices from moderate resolution satellite soil moisture data over Northwest Spain. Remote Sensing, v.9, p.1-21, 2017. https://doi. org/10.3390/rs9111168

Paredes-Trejo, F.; Barbosa, H. Evaluation of the SMOS-Derived soil water deficit index as agricultural drought index in Northeast of Brazil. Water, v.9, p.1-21, 2017. https://doi.org/10.3390/w9060377

Pernambuco. Secretaria de Ciência, Tecnologia e Meio Ambiente. Atlas de bacias hidrográficas de Pernambuco. Recife: Pernambuco, 2005. 104p.

Rossato, L.; Alvalá, R. C. dos S.; Marengo, J. A.; Zeri, M.; Cunha, A. P. M. do A.; Pires, L. B. M.; Barbosa, H. A. Impact of soil moisture on crop yields over Brazilian semiarid. Frontiers of Environmental Science \& Engineering, v.5, p.1-16, 2017. https://doi.org/10.3389/ fenvs.2017.00073

Souza, A. G. S. S.; Ribeiro Neto, A.; Rossato, L.; Alvalá, R. C. S.; Souza, L. L. Use of SMOS L3 Soil Moisture Data: Validation and drought assessment for Pernambuco state, Northeast Brazil. Remote Sensing, v.10, p.1-19, 2018. https://doi.org/10.3390/rs10081314

Spinoni, J.; Naumann, G.; Carrão, H.; Barbosa, P.; Vogt, J. World drought frequency, duration, and severity for 1951-2010. International Journal of Climatology, v.34, p.2792-2804, 2014. https://doi.org/10.1002/joc.3875

Wood, E. F.; Sheffield, J. Drought: Past problems and future scenarios. 1 ed. New Jersey: Routledge, 2012. 248p. https://doi. org/10.4324/9781849775250

Zeri, M.; Alvalá, R. C. dos S.; Carneiro, R.; Zeri, G. C.; Costa, J. M.; Spatafora, L. R.; Urbano, D.; Vall-Llossera, M.; Marengo, J. Tools for communicating agricultural drought over the Brazilian semiarid using the soil moisture index. Water, v. 10, p. 1-15, 2018. https://doi.org/10.3390/w10101421

Zhang, A.; Jia, G. Monitoring meteorological drought in semiarid regions using multi-sensor microwave remote sensing data. Remote Sensing of Environment, v.134, p.12-23, 2013. https:// doi.org/10.1016/j.rse.2013.02.023

Zhang, L.; Jiao, W.; Zhang, H.; Huang, C.; Tong, Q. Studying drought phenomena in the continental United States in 2011 and 2012 using various drought indices. Remote Sensing of Environment, v.190, p.96-106, 2017. https://doi.org/10.1016/j.rse.2016.12.010 